\title{
Formation of Technological Competence in Students: Essence and Content
}

\author{
Allambergenov Akhmet Janabergenovich,
}

\begin{abstract}
Annotation This article reveals the essence and content of formation of technological competence in students.
\end{abstract}

Keywords: technology, competence, knowledge, ability, culture, technological competence, technological worldview

\section{INTRODUCTION}

The second half of the 20th century and the beginning of the 21 st century were characterized by a sharp increase in the volume of social production in the world, the emergence of computer technologies and new as well as material and energy saving high technologies. The third technological revolution began in the history of mankind, a post-industrial society appeared with a high level of mental workers - the "white-collar" society, which replaced the industrial society of conveyor production - the "blue-collar" society. A sharp increase in the amount of used information led to the creation of the information world.

The technological revolution of the 21 st century associated with the intensive development and use of nanotechnology, robotics, biotechnology and other promising technologies requires the formation of scientific and technological potential in our country that is adequate to the modern requirements of global technological development.

Training personnel potential for solving scientific and practical tasks should begin with a study of the educational area "Technology" in secondary schools and continue in primary, secondary and higher vocational schools. While studying the educational area "Technology", students should be able to analyze and creatively solve arising practical problems, have initial ideas about the transformation of materials, energy and information, the design, planning and manufacturing, the evaluation of processes and products, knowledge and skills in the field of technical or artistic applied arts, imaginations about the world of science, technology and technological sphere, the impact of technology on society and the environment, the spheres of human activity and public production, the world of professions and ways of self-assessment of own capabilities.

As the world experience in general education of youths shows, the educational area "Technology" is a necessary

Revised Manuscript Received on September 25, 2019

Allambergenov Akhmet Janabergenovich, teacher of the Karakalpak State University, Nukus city, the Republic of Uzbekistan. component of schoolchildren's general education giving them the opportunity to apply in practice and creatively use the knowledge of the basics of sciences in the field of design and manufacturing of products. This ensures the continuity of the transition of students from general to vocational education, continuous self-education and work. Therefore, in many developed countries, "Technology" is one of the main educational subjects from kindergarten to high school graduation [2].

\section{MAIN PART}

The main purpose of the educational area "Technology" in the general education system is the formation of schoolchildren's technological literacy, technological competence, technological worldview and technological culture, formation of the system of technological knowledge and skills, fostering labor, civic and patriotic qualities in students' personality, professional self-determination in the labor market, and the formation of a humanistic oriented outlook.

Analysis of Internet resources shows that in the production sphere, technological competence refers to the ability of company employees to develop and market high-quality products based on advanced technologies [3].

In philosophical literature, technological competence is considered by researchers as the ability of a person to humanize the technological sphere and solve the ecological survival problem of humanity in the 21 st century. In the philosophy of technology, technological competence is represented in several senses: as characteristics of a creative person - creativity, knowledge and skills (P.K. Engelmeyer) [4]; as the ability to master complex technologies based on the unity of high qualification obtained in the course of training and continuous self-development (A.I. Rakitov) [5]. In psychological science, technological competence is defined as a private construct, as one of the components of professional competence. Technological competence of a specialist is "the availability of knowledge, skills and abilities in him to do the job he was trained for, work with technical means of the activity in the systems "man machine" in the conditions of this type of work, in the amount not less than the required qualification standards" [6].

In pedagogical science, the problem of technological competence/competence of specialists is investigated in the context of technological competence of future technology teachers (Yu.S. Dorokhin, A.N. Sergeev) [7; 8]; technological competence of 
service specialists (O.A. Smolin) [9].

Analysis of psychological and pedagogical literature shows that the construct of "technological competence" in the middle of the 20th century is identified with the possession of generalized labor / polytechnic skills by specialists. In the 60s-70s of the 20th century, researchers in pedagogy studied such categories as "general polytechnic labor skills" (E.A. Milerian) [10] and "industry-wide technological knowledge and skills" (E.M. Kalitsky) [11].

The results of the study showed that at present the term "technological competence" has an ambiguous interpretation.

The most accurate and comprehensive definition of technological competence is presented by S.F. Ekhov [12, p.24]. According to him, technological competence is one of the stages of man's mastery of technological culture as an integral part of human culture. The researcher uses the following hierarchy of concepts: technological literacy technological education - technological competence technological worldview.

Based on the results of researches to determine the structure of technological competence, the following invariant components of the structure of this category are determined: value-motivational, cognitive and reflexive-evaluative [13, p.24].

\section{TheOretical BaCKGROUND}

The value-motivational component designed to develop value orientation in students is a complex socio-psychological phenomenon that determines the direction and activity of an individual, his actions and behavior, his attitude to the surrounding reality, work, and the chosen profession. Value orientations establish the level of motives.

The second component of the content of technological competence is a cognitive-activity component. Analysis of the works of Russian and domestic researchers shows that competencies include generalized knowledge and skills. Thus, in the work by E.A. Millerian, the basis for workers' effective professional training is represented by "generalized, flexible, easily transferable general technical knowledge, skills and abilities" [14, p.31].

Hence, generalized knowledge and skills are the most important components of a person's competence, and the content of the cognitive-activity component of technological competence can be represented by generalized technological knowledge, on the basis of which skills in the mastery and use of technology in various conditions are formed. To clarify the content of the category "technological knowledge", the definition by V.D.Simonenko can be used: "Technological knowledge is the knowledge about the methods of transformative activity, including the knowledge about the means, objects and results of this activity" [15, p.90].

Thus, the content of the cognitive-activity component of students' technological competence consists of generalized technological knowledge and skills.

For productive professional activity, a modern specialist needs to select used technologies to assess their effectiveness, determine the degree of their risks (for the environment, workers, consumers, etc.) during introduction, adapt them, create and implement innovative technologies in professional activity. A specialist can carry out such types of work on the basis of various forms of critical and reflexive thinking. In this regard, in our study, one of the components of technological competence of future specialists is the reflexive-evaluative component, which is aimed at developing students' ability to self-analyze own activities and evaluate the achieved results. Due to the formation of the component of technological competence in students, the functions of monitoring and evaluation carried out mainly by teachers in the course of technological training are transferred to the self-control and self-assessment of students.

Reflexive self-assessment means the knowledge of one's own knowledge and ignorance, one's own capabilities and limitations. According to R. Boyatzis, people with self-assessment "are able to describe and evaluate the effectiveness of their activities in a particular situation" [15, p.159]. Self-assessment helps students start thinking about themselves in terms of competency indicators.

At present, it is becoming clear that the components of technological competence should be formed during the study of technology starting from primary school. It is important to emphasize that regardless of the type of specific technology that people currently use, they deal with the invariant components of human activity: work culture, graphic culture (creating and using graphic images while doing work), information culture (using various sources of information while doing work), ecological culture (careful attitude to nature and human health, saving materials and energy, recycling waste), design culture, home culture, consumer culture, culture of human relations and project culture.

Information culture - the culture of receiving and working with information, and project culture - the culture of doing projects play a special role in the modern world. Technological culture is necessary when choosing any profession from turner to doctor, and from teacher and to programmer.

In general education system, the educational area "Technology" is designed to: form in students an inner need and a respectful attitude towards work; lay the foundation for successful creative and transformative activities; form a research, technological, labor, ethical, aesthetic, ecological, entrepreneurial, graphic and information culture in students; acquaint students with various types of professional activity and promote their professional self-determination; identify and develop schoolchildren's abilities in creative and transformative activity; form and expand their cognitive interests, consciousness and flexibility; promote self-realization, self-assertion and socialization in schoolchildren in peer groups during the period of study.

\section{CONCLUSION}

While fulfilling its mission, the educational area "Technology" makes a significant contribution to the development of 
a holistic personality that harmoniously combines the needs for physical and mental work, constant self-education and self-improvement.

The knowledge and skills formed in schoolchildren while studying the educational area "Technology" create cultural and spiritual prerequisites for the preservation and development of national cultures, and for the innovative socio-economic development of the country.

\section{LITERATURE}

1. Standards for Technology Literacy. Content for the Study of Technology Education, Association and its Technology for all American Project, Reston< Virginia, 2000, 248 p.

2. "Güring" firm and its products [Electronic resource]. - 2011

3. P.K. Engelmeyer. Creative person and environment in the field of technical inventions. St. Petersburg, 1911. - 116 p.

4. A.I. Rakitov. Prolegomena to the idea of technology // Questions of Philosophy. - 2011. - № 1. - pp. 3-14.

5. Technological competence of a specialist // Psychophysiology of a person: Russian-English-Russian encyclopedia / Comp. E.V. Trifonov [Electronic resource]. - 14th ed. - 2011.

6. Yu.S. Dorokhin. Formation of technological competence in future teachers in the study of disciplines of specialized training: abstract of dis. ... cand. ped. sciences: 13.00.08; Tula State Pedagogical University. - Tula, 2010. $23 \mathrm{p}$.

7. A.N. Sergeev. Technological training of future teachers in the context of paradigmatic transformation of education (on the example of the specialty: 050502.65 - technology and entrepreneurship): abstract of dis .... doctor of ped. sciences: 13.00.08; Tula State Pedagogical University. - Tula, 2010. $50 \mathrm{p}$.

8. O.A. Smolina. Formation of technological competence in future service specialists in higher education establishment: abstract of dis. ... cand. ped. sciences: 13.00.08; South-Ural State University. - Chelyabinsk, 2010. - 26 p.

9. E.A. Milerian. Psychology of formation of general polytechnic labor. Moscow: Pedagogy, 1973.

10. E.M. Kalitsky. Formation of industry-wide technological knowledge and skills in students of secondary vocational schools (on the example of training metalworkers): abstract of dis. ... cand. ped. sciences: 13.00.02; APS of the USSR, Scientific Research Institute. Content and methods of teaching. - Moscow, 1978. - 23 p.

11. S.F. Ekhov. The change of the paradigm of technological education as an objective necessity // Technological education: problems and prospects of interaction between the university and the school: monograph / responsible ed. P.A. Petryakov; Novgorod State University. - V. Novgorod, 2008. - pp 13-27.

12. A.V. Koklevsky. Formation of technological competence in future specialists in the process of military training in a classical university: theory and practice. - Minsk: RIHE, 2015. - 228 p.

13. Technological system of training students in secondary vocational schools / Ye.A. Milierian [and others]. - Yerevan: Luys, 1985. - 192 p.

14. V.D. Simonenko. Technological culture and education (cultural-technological concept of the development of society and education). - Bryansk: BPTU publishing house, 2001. - $214 \mathrm{p}$.

15. R. Boyatzis. Competent Manager. Model of effective work; trans. from English. - Moscow: HIPPO, 2008. - XII, 340 p. 